\title{
THE EFFECT OF INSTAGRAM IN LEARNING ENGLISH VOCABULARY
}

\author{
Alfu Habibah ${ }^{1}$ \\ Nur Asmawati ${ }^{2}$ \\ Fitriningsih Fitriningsih ${ }^{3}$ \\ Nurdin Nurdin ${ }^{4}$ \\ 1,2,3 English Tadris Study Program, Faculty of Tarbiyah And Teacher Training \\ State Institute for Islamic Studies Palu \\ ${ }^{4}$ Faculty of Islamic Economic and Business, State Institute for Islamic Studies Palu \\ ${ }^{4}$ Corresponding author, \\ Email: nnurdin@iainpalu.ac.id
}

\begin{abstract}
The aims of this research are to find out the effect of Instagram in learning vocabulary of third semester students at English Tadris Study Program in IAIN Palu. This research was quantitative method and used total sampling. The subject of this research was the students' batch 2019 semester 3 academic year 2020-2021 in IAIN Palu. The total numbers of students of in this research were 102 students. After selected the sample of this research were 35 students. Research instrument is questionnaire. The technique of collection data was observation, and reduction. The result showed that Effect of Instagram in Learning Vocabulary of Third Semester Students' at English Tadris Study Program in IAIN Palu Academic year 2020/2021, used online media namely google form. The data revealed that the level of the mean score $62,48 \%$ from 35 students which was categorized as high effect. Then the research concluded that it is evident that Instagram have an effect on learning English (vocabulary) of student. It was revealed by the mean score $62,48 \%$. The research was classified as high category of the students' questionnaire.
\end{abstract}

Keywords: English learning, vocabulary, Instagram 


\section{Background}

Learning system by teaching students through the internet or online learning environment. Students access class goals, lecture notes, teaching materials, and examinations via the internet. Students and instructors interact online through email, chat rooms and thread discussions. Also known as web-based classrooms, elearning, virtual education, and distance learning. Once considered a trend, social media one of online learning has evolved into a "timely" teaching hybrid anytime, anywhere. ${ }^{1}$

Internet and social networking applications as well as interacting and communicating media can also be used as learning media that have supported the transformation of science including applicative, literary or theoretical theories of social learning. ${ }^{2}$ With this, internet and social networking can use learning with social media. It is now a lot happening in the process of distance education (elearning) where the learning process is no longer limited to classrooms, distance, and time. Limited classroom for learning vocabulary by using social media not limited nowadays, hence using social media can be media learning tools. Social media It

${ }^{1}$ Hasnawati Hassan, ' Students Engagement

In Online Learning: Learners Attitude Toward E-

Mentoring, 'www.researchgate.net (20 february 2021).

\footnotetext{
${ }^{2}$ Maryani.."MediaSosialdalam Dunia Pendidkan", AnNahdhahhttps://www.google.com/url?sa=t\&source= web\&rct=http://www.researchgate.net $\quad(15$ October 2020).
}

has become one of the most popular media that facilitates students being to communicate. It can be used as a media to link one another, even though they cannot face each other due to routine activity. So that Social media in educational activities have a big influence to help the student or learner to study. The students can use social media as the source for their studies and practice their skills. $^{3}$

Instagram is one of social media such an amazing application and one of the most popular social media applications. ${ }^{4}$ What makes it the best application in learning English language is that its users learn in an entertaining and spontaneous way. Instagram has a beneficial characteristic as it falls in the category of social networking and the main source of networking is communication. ${ }^{5}$ According to Napoleon, there are 40 Million Instagram users, which are divided into $52 \%$ male and $48 \%$ female. Over $80 \%$ of them are aged from 18 to 44 years.Interestingly, this application is used as a place of learning in the world of education, the presence of additional features as interactions as well as additional learning activities outside of

${ }^{3}$ UlfaAzkiya. ' 'Students Perception Towards the Impact of English Learning Accounts on Instagram On Students' Vocabulary,https://www.google.com/url?sa=t\&sourc e=web\&rct=http://repository.ar-raniry.ac.id $\quad(01$ October 2020).

${ }^{4}$ Pero Ali, ' 'Instagram in Learning English Language,' 'http://prezi.com/orhxy6-

Icpc8/instagram-in-learning-ssenglishlanguage/. (20 November 2020).

${ }^{5}$ Noraien, M. and Normaliza, A. R. 'Instagram in ESL classroom,', Man in India, 2017. https://www.researchgate.net/publication

1321016352_INSTAGRAM_IN_ESL_CLASROOM (01 October 2020) 
school. ${ }^{6}$ Wiktorstate that Instagram has some essential tools that could benefit in educational purposes related to linguistic intelligences (vocabulary). Ferlazzo in Blair and Serafini state that: if students learn English, Instagram can help them improve their mastery of English vocabulary. ${ }^{7}$

Vocabulary is one of the most important components of language and one of things that to be noticed by the linguists. ${ }^{8}$ Vocabulary refers to a list or set of words for a particularly language or a list or set of words that individual speakers of language might use. ${ }^{9}$ To enhance students vocabulary in learning language the Effective strategies help students understand and learn a new word. English learners need a good strategy for vocabulary learning makes them easy to remember and learn vocabulary. ${ }^{10}$

\footnotetext{
${ }^{6}$ Ronan Kelly. 'An Exploration of Instagram to Develop ESL Learners' Writing Proficiency," (Doctoral dissertation, Ulster University). London, United Kingdom: British Council, 2015. https://www.google.com/url?sa=t\&source=web\&rct =http://repository.ar-raniry.ac.id (01 October 2020)

${ }^{7}$ Henny mastuti. Thesis. 'Penggunaan Instagram untuk Meningkatkan Penguasaan Kosa Kata Bahasa Inggris,' https://www.google.com/url?sa=t\&source=web\&rct =http://repository.ar-raniry.ac.id (01 october 2020).

${ }^{8}$ jack c. Richards, Curriculum Development In Language Teaching, (united kingdom: cambridge university press, 2002. Www.amazon.com (22 february 2021)

${ }^{9}$ hatch, evelyn and brown. Vocabulary, Semantics, And Langauge Education. Cambridge :cambridge university press, 1995.www.uptjournals.net (09 october 2020)

${ }^{10}$ Mulyasari, Hartati, t. 'Meaningful Vocabularies Developed Through Classroom Activities. Conferenced: 3rd international conference on early childhood education,', Https://www.google.com/url?sa=t\&source=web\&rct =http://repository.ar-raniry.ac.id (01 october 2020)
}

The research background by sub optimal vocabulary needs based on interview from the vocabulary lecturer in IAIN Palu. The researcher interests in doing research at 2019 IAIN Palu English tadris study program, because in general students have social media like Instagram to communicate with their friends to get information or learn English based on observation. Besides, students tend to prefer use social media in daily activities and learning activities.

In this study, we will answer the following research question "Is there an effect of Instagram in learning Vocabulary of third semester, students' at English tadris study program in IAIN Palu academic year 2020/2021?"

\section{Literature Review}

\subsection{Previous Studies}

In this study, the researchers did some reviews from previous studies. The function of previous studies is to support the researcher or to take the differences between those previous studies

The first research is done by Ramdhany (2017) conducted the study about students ${ }^{\text {ee }}$ Interest in Learning Vocabulary through Instagram at the fifth semester of English Department of UIN Alauddin Makassar', This research discussed the way of students ${ }^{\text {ee }}$ interest in learning vocabulary through Instagram. It used a descriptive quantitative method with 85 participants. The researcher concludes that the students ${ }^{\text {ee }}$ interest was in high level because the participant was engaged, care and had a positive feeling in learning vocabulary through Instagram. ${ }^{11}$

\footnotetext{
${ }^{11}$ Ramdhany thesis. "Students Interest In Learning Vocabulary Through Instagram At The
} 
The second research done by Ulfaazkiya (2019) entitled ' Students' Perception Towards the Impact of English Learning Accounts on Instagram On Students' Vocabulary'. The qualitative method was used in conducting this study and to obtain the data, the researcher used semi-structured interview. The result of this study are students" perceive learning vocabulary by using English learning Accounts on Instagram was really supporting their learning and they have good experienced during learning vocabulary through Instagram. ${ }^{12}$

The third research done by Nurul zahrizan (2019) entitled " The Influence accoumt @ gurukumrd to the out of class Language Learning (Study on Easiness of Followers' English Learning at IState Islamic College of Sorong)'. The type of research is quantitative using Ex Post-Facto method. The sample taken was students who became followers of @gurukumrd, amounting to 22 people. The sampling technique uses purposive sampling technique. The researcher used instrument Likeart scale questionnaire. The data that has been collected is then processed use help of the SPSS (Statistical Program for Social Science) for windows version 20. The result showed that there was an influence of the instagram account @ gurukumrd to out of class English

Fifth Semester Of English Department Of UinAlauddin Makassar," 2017. https://www.google.com/url?sa=t\&source=web\&rct $=$ http://repository.uin-alauddin.ac.id(04August 2019).

\footnotetext{
${ }^{12}$ UlfaAzkiya. "Students Perception Towards the Impact of English Learning Accounts on Instagram On Students' Vocabulary, ' 'https://www.google.com/url?sa=t\&source=web\&rc $\mathrm{t}=\mathrm{http}: / /$ repository.ar-raniry.ac.id (01 October 2020).
}

Language Learning on Students who were followers of @ gurukumrd. ${ }^{13}$

Based on those previous researches, there are any different the first researcher focused intereststudents' learning vocabulary through Instagram.

While the second researcher focused on students' perception towards the impact of English learning accounts on Instagram on students' vocabulary, used qualitative method and interview. Five students were selected purposively as the participants of study.

The third researcher focused on account@gurukumrd and used purposive sampling the result show that Instagram @gurukumrd social media accounts have positive influence on someone' learning and are significant for out of class English language learning of student and based on the result of questionnaire which @gurukumrd as alternative teacher in their Instagram account can improve their skill every day and followers has a good directed naturalistic language learning. In this research, the researcher will focus on effect of learning vocabulary through Instagram.

\subsection{Social Media}

Social media is a prominent medium of communication and used by all generations. Besides being used as a tool of communication, institutions have integrated social media such Instagram as learning tools to deliver new information and connect with students. ${ }^{14}$ Students also are

${ }^{13}$ Nurul zahriza.The Influenceaccoumt
@ gurukumrd to the out of class Language Learning
(Study on Easiness of Followers' English Learningat
State Islamic College of Sorong)', 2019.
https://www.google.com/url?sa=t\&source=web\&rct
=http://www.researchgate.net (15 October 2020)
Social Media and Its Influence on Vocabulary and
Language Learning: A Case Study in


exposed to interaction with other individuals around the world using social media. The use of social media has positive impacts on learning foreign language. ${ }^{15}$ Social media platforms are perceived as effective tools in language learning. The impacts of social media on second and foreign language acquisition it is more effective to learn via social media compared to traditional learning. ${ }^{16}$ Social media provides students on the usage of words in an authentic real-life situation verb, noun and adjective. ${ }^{17}$ The use of social media also provides positive effects such as pronunciation improvement and vocabulary enlargement resulted from the use of social media. ${ }^{18}$ When using social media, students

UniversitiTeknologi Mara (Uitm), Shah Alam, Malaysia,": European Journal of Education Studies. $:$ :https://www.researchgate.net/publicatio n/344349821 (13 March 2021).

${ }^{15}$ Bicen, H., \&Sadikoglu, S., \&Sadikoglu,
G,'’The Impact of Social Networks on
Undergraduate Students Learning Foreign
Language. Procedia: Social and Behavioral
Sciences.
https://www.researchgate.net/publication/344349821
(13 March 2021).

${ }^{16}$ Alharty, K. \& Alfaki, I. M. (2014). Towards a Digital World: Using Social Networks to Promote Learner's Language. Towards a Digital World: Using Social Networks to Promote Learner's Language,

http://www.aijcrnet.com/journals/Vol_4_No_10_Oct ober_2014/13.pdf. (13 March 2021)

${ }^{17}$ Zahirah Zainal, Noor HanimRahmat, " Social Media and Its Influence on Vocabulary and Language Learning: A Case Study in UniversitiTeknologi Mara (Uitm), Shah Alam, Malaysia,": European Journal of Education Studies. :https://www.researchgate.net/publication/34434982 1 (13 March 2021).

${ }^{18}$ Abbasova, M. (2016). The Impact of Social Networks on the Students' English Language in Azerbaijan. International Multidisciplinary Scientific Conferences on Social Sciences and Arts, 3. are given the chance to learn vocabulary by using strategies such as collaborating with other social media users in comment sections and this will provide an opportunity for them to learn new words. Repeated exposures in social media occur when students get to look at the words constantly and they tend to remember the word subconsciously. Words such as profile, comment, like and post are some of the examples of words that are repeatedly exposed when using social media such as Instagram. ${ }^{19}$

\subsection{Instagram}

Instagram is for posting their photos and videos, it's not just about your selfies, food, and fitness photos, and likes, as the internet makes the education process more interesting than ever. $^{20}$ According kirst Instagram can be a great educational tool that makes the educational process interesting and insightful. ${ }^{21}$ It can be a good

https://www.researchgate.net/publication/307967123 _The_Impact_of_Social_Net

works_on_the_Students'_English_Language_in_Aze rbaijan (13 March 2021).

${ }^{19}$ SutasiniSivagnanam, Melor Md Yunus,' Utilizing Social Media in Vocabulary Enhancement among Primary ESL Learners in 1Sekolah KebangsaanBatuKikir, Negeri Sembilan, Malaysia 2Faculty of Education, UniversitiKebangsaan Malaysia,": Universal Journal of Educational Research. http://www.hrpbug.org (13 March 2021).

${ }^{20}$ Dr.Micahel W. Kirst . "A College Succes the College Puzzle," Stanford University, 2016.: http://collegepuzzle.stanford.edu/?p=5057Language. International Journal of Teaching and Education (02 October 2020)

${ }^{21}$ Kirst, Michael W. Instagram as an Educational Tool for College Students. 2018.

:

http://collegepuzzle. stanford.edu/?p=5057Language. International Journal of Teaching and Education (01 October 2020) 
opportunity to use Instagram in learning process.

Instagram offers a lot of contextualized visual information and can be very useful in the education setting because it provides visual elements for visual students". 22

Instagram application has features all of which are located at the bottom. These applications features are:

a. Home page, the main page displays the timeline of the latest photos Instagram users, comments, photos on Instagram can be commented on in the column comment

b. Profile, In the Profile page we can find out in detail about user1 information, both ourselves and others the user.

c. News Feed, This feature displays notifications for various activities1done by Instagram users. In addition, according to Atmoko, there are some parts that should be filled so that the photos we upload are more informative. The parts that is:

\section{a. Caption}

Making captions or photo titles is more reinforcing the character or message to be conveyed in the photo.

b. Hashtag

Hashtag is a label in the form of a word prefixed symbol in the form of a fence (\#). This feature is important because it can make it easy for users to find photos on Instagram with certain labels. ${ }^{23}$ If want to

\footnotetext{
${ }^{22}$ Yadegarfar, H. \&Simin, S. Effects of using Instagram on learning grammatical accuracy of word classes among Iranian undergraduate TEFL students, 2016. International Journal of Research Studies in Educational Technology. Retrieved on 15 July 2018, from: https://www.learntechlib.org/p/173362 (01 October 2020)

${ }^{23}$ Ardianto, Thesis 'PengaruhAkun Media Sosial Instagram
}

get motivation, hashtag can help search for images, using relevant hashtags (\#students, \#vocabulary, \#language).

\subsection{Vocabulary}

Vocabulary mastery is having the ability to correctly define and use each word appropriately in a sentence. ${ }^{24}$ Vocabulary is all the words that a person knows or uses, all the word in a language, list of words with their meanings. ${ }^{25}$ Vocabulary helps students learn the four basic skills of English.

Vocabulary is one of important things to be taught in learning foreign language because it will be impossible to be speak up without variety words. ${ }^{26}$ Vocabulary learning is important because it is needed by learners to acquire a lot of words so they can use the vocabulary in any needs especially academic needs. ${ }^{27}$ Vocabulary is a basis of language, it is very important to master in our language.

@pemudahijrahterhadapperilakuremaja"' :Studi pada Siswa-siswi MAN Model Kota Sorong, Papua Barat, 2018

https://www.google.com/url?sa=t\&source=web\&rct $=$ http://repository.ar-raniry.ac.id ( 10 November 2020)

${ }^{24}$ Cameron, L. Teaching languages to young learners. Cambridge: Cambridge University Press, 2001.

https://www.google.com/url?sa=t\&source=web\&rct =http://repository.ar-raniry.ac.id (01 October 2020)

${ }^{25}$ Ed. Victoria Bull, Oxford Learner's

Pocket Dictionary, 4th edition. New York: Oxford University Press. 2008. www.amazaon.com (01 October 2020)

\footnotetext{
${ }^{26}$ Ur, Penny. 'A Course in Language Teaching. Practice and Theory.' Cambridge: Cambridge University Press, 1996.www.amazon.com (20 November 2020)

${ }^{27}$ Komachali and Khodareza, 2012 in Elsa YuriskaSitompul "Teaching Vocabulary Using Flashcards And Word List."http:// www.amazon.com (02 October 2020).
} 
Based on the statement above, the researcher assumes that vocabulary is an important role in learning a language, vocabulary is also as the core component of language in form of words and can make language meaningful. To communicate effectively, the learners need an adequate mastery of vocabulary. ${ }^{28}$

\section{Methodology}

This study used quantitative approach in which the data was collected through survey.

According Wahyu Hidayat and Nur Asmawati Lawahid state that researchers design a questionnaire with questions that are relevant to the research problem or study. ${ }^{29}$ The survey is the process by which the researcher collects data through a questionnaire. ${ }^{30}$ Questionnaire is a number of written questions, which is used to gain information from respondents themselves. ${ }^{31}$ Questionnaire in this study the questionnaire uses to obtain data on the effect of Instagram in learning Vocabulary of third semester students at English Tadris Study Program in IAIN Palu academic year 2020/2021. The questionnaire use in this study is close questionnaire.

\footnotetext{
${ }^{28}$ Meydina. Thesis. The effect of applying word sort strategy toward students' vocabulary mastery of the eight grade (Students At Smp Negeri 3 Palu ), 2019.

$\begin{array}{ccrr}{ }^{29} \text { Wahyu } & \text { Hidayat } & \text { dan } & \text { Nur } \\ \text { AsmawatiLawahid. } & \text { Metode } & \text { Fuzzy } & \text { Delphi }\end{array}$ UntukPenelitianSosial (Bandung), 2020.

${ }^{30}$ O'Leary,Z. 'The Essential Guide To Doing Your Research Project,' (London: Sage, 2014). www.amazon.com (20 November 2020).

${ }^{31}$ Arikunto, S.

ProsedurPenelitianSuatuPendekatanPraktek, edisirevisi VI, PT: RinekaCipta, Jakarta, 2002. https://www.google.com/url?sa=t\&source=web\&rct =http://www.researchgate.net (15 Oktober 2020).
}

The data analysis techniques used is the arranged categorize the data obtained from the distribution of questionnaires to then be processed using SPSS (Statistical Program for social science) for windows version 25.

\section{Result and Discussion}

\subsection{Findings}

In this part, the data collected from 35 students and scored the questionnaire by percentage analyzing. Based on the result a detailed explanation regarding each question item. Table 1 below shows the validity test.

Table 1. Validity test

\begin{tabular}{|l|l|r|r|r|r|}
\hline \multicolumn{2}{|c|}{} & $\begin{array}{r}\text { Frequ } \\
\text { ency }\end{array}$ & Percent & \multicolumn{1}{c|}{$\begin{array}{c}\text { Valid } \\
\text { Percent }\end{array}$} & \multicolumn{1}{c|}{$\begin{array}{c}\text { Cumulative } \\
\text { Percent }\end{array}$} \\
\hline \multirow{7}{*}{ Valid } & 2.00 & 1 & 2.9 & 2.9 & 2.9 \\
\cline { 2 - 6 } & 3.00 & 26 & 74.3 & 74.3 & 77.1 \\
\cline { 2 - 6 } & 4.00 & 8 & 22.9 & 22.9 & 100.0 \\
\cline { 2 - 6 } & Total & 35 & 100.0 & 100.0 & \\
\hline
\end{tabular}

Table 1 above indicates that 1 of 35 students are disagree, 26 students are agree, 8 students are strongly agree and It can be said that they are agree Interest in learning English (vocabulary) through Instagram.

The table 2 below shows learning through Instagram is more interesting than just reading a book or listening to material.

Table2. Learning interest on Instagram 
Datokarama English Education Journal Vol.2 No. 1, 2021

\begin{tabular}{|l|l|r|r|r|r|}
\hline \multicolumn{2}{|c|}{} & $\begin{array}{c}\text { Frequen } \\
\text { cy }\end{array}$ & Percent & \multicolumn{1}{|c|}{$\begin{array}{c}\text { Valid } \\
\text { Percent }\end{array}$} & $\begin{array}{c}\text { Cumulative } \\
\text { Percent }\end{array}$ \\
\hline Valid & 1.00 & 1 & 2.9 & 2.9 & 2.9 \\
\cline { 2 - 6 } & 2.00 & 8 & 22.9 & 22.9 & 25.7 \\
\cline { 2 - 6 } & 3.00 & 20 & 57.1 & 57.1 & 82.9 \\
\cline { 2 - 6 } & 4.00 & 6 & 17.1 & 17.1 & 100.0 \\
\cline { 2 - 6 } & Total & 35 & 100.0 & 100.0 & \\
\hline
\end{tabular}

Table 2 above indicates that 1 of 35 students is strongly disagree, 8 students are disagreeing, 20 students are agreeing, 6 students are strongly agreeing and It can be said that they are agree Learning through Instgram is more interesting than just reading a book or listening to material.

Table 3.Videos posted on Instagram can improve vocabulary skills

\begin{tabular}{|l|l|r|r|r|r|}
\hline \multicolumn{2}{|l|}{} & $\begin{array}{c}\text { Frequen } \\
\text { cy }\end{array}$ & Percent & \multicolumn{1}{c|}{$\begin{array}{c}\text { Valid } \\
\text { Percent }\end{array}$} & $\begin{array}{c}\text { Cumulative } \\
\text { Percent }\end{array}$ \\
\hline \multirow{3}{*}{ Valid } & 3.00 & 28 & 80.0 & 80.0 & 80.0 \\
\cline { 2 - 6 } & 4.00 & 7 & 20.0 & 20.0 & 100.0 \\
\cline { 2 - 6 } & Total & 35 & 100.0 & 100.0 & \\
\hline
\end{tabular}

Table 3 above indicates that 28 of 35 students are agree, 7 students are strongly agreeing and It can be said that they are agree Videos posted on Instagram can improve vocabulary skills.

Table 4. Instagram can affect the improvement of learning English vocabulary.

\begin{tabular}{|l|l|r|r|r|r|}
\hline \multicolumn{2}{|c|}{} & $\begin{array}{r}\text { Frequen } \\
\text { cy }\end{array}$ & Percent & $\begin{array}{r}\text { Valid } \\
\text { Percent }\end{array}$ & \multicolumn{1}{c|}{$\begin{array}{c}\text { Cumulative } \\
\text { Percent }\end{array}$} \\
\hline Valid & 2.00 & 1 & 2.9 & 2.9 & 2.9 \\
\cline { 2 - 7 } & 3.00 & 27 & 77.1 & 77.1 & 80.0 \\
\cline { 2 - 7 } & 4.00 & 7 & 20.0 & 20.0 & 100.0 \\
\cline { 2 - 7 } & Total & 35 & 100.0 & 100.0 & \\
\hline
\end{tabular}

Table 4 above indicates that 1 of 35 students are disagree, 27 students are agreeing, 7 students are strongly agreeing and It can be said that they are agree Instagram can affect the improvement of learning English (vocabulary).

Table 5. Follower gets lot of English learning tips on Instagram

\begin{tabular}{|l|l|r|r|r|r|}
\hline \multicolumn{2}{|l|}{} & $\begin{array}{c}\text { Frequen } \\
\text { cy }\end{array}$ & Percent & \multicolumn{1}{c|}{$\begin{array}{c}\text { Valid } \\
\text { Percent }\end{array}$} & $\begin{array}{c}\text { Cumulative } \\
\text { Percent }\end{array}$ \\
\hline Valid & 2.00 & 5 & 14.3 & 14.3 & 14.3 \\
\cline { 2 - 6 } & 3.00 & 21 & 60.0 & 60.0 & 74.3 \\
\cline { 2 - 6 } & 4.00 & 9 & 25.7 & 25.7 & 100.0 \\
\cline { 2 - 6 } & Total & 35 & 100.0 & 100.0 & \\
\hline
\end{tabular}

Table 5 above indicates that 5 of 35 students are disagree, 21 students are agreeing, 9 students are strongly agreeing and It can be said that they are agree Follower gets lot of English learning tips on Instagram.

Table 6.Learning Instagram helps to understand English vocabulary material better. 
Datokarama English Education Journal Vol.2 No. 1, 2021

\begin{tabular}{|l|l|r|r|r|r|}
\hline \multicolumn{2}{|c|}{} & $\begin{array}{c}\text { Frequen } \\
\text { cy }\end{array}$ & Percent & \multicolumn{1}{c|}{$\begin{array}{c}\text { Valid } \\
\text { Percent }\end{array}$} & $\begin{array}{c}\text { Cumulative } \\
\text { Percent }\end{array}$ \\
\hline Valid & 1.00 & 1 & 2.9 & 2.9 & 2.9 \\
\cline { 2 - 6 } & 3.00 & 22 & 62.9 & 62.9 & 65.7 \\
\cline { 2 - 6 } & 4.00 & 12 & 34.3 & 34.3 & 100.0 \\
\cline { 2 - 6 } & Total & 35 & 100.0 & 100.0 & \\
\hline
\end{tabular}

Table 6 above indicates that 1 of 35 students are strongly disagree, 22 students are agreeing, 12 students are strongly agreeing and It can be said that they are agree Learning through video in learning English accounts on Instagram helps to understand English vocabulary material better.

Based on the data finding above, the effect of using Instagram on the learning vocabulary of 2019 third semester English tadris study program IAIN Palu academic year 2020-2021 was categorized as high. This is reflected by the mean score of their effect in learning vocabulary through Instagram was $62,48 \%$. It means that the most of students was effect in learning vocabulary through Instagram. If we pay attention on the results which show that most of respondents agree Instagram makes educational process insightful.

We sometimes hear that for interesting a lesson we should love with the subject. In this case, the statements are relevant to previous studies which shows that there are $74,3 \%$ of the respondents who agree Instagram makes the educational process interesting.

The data on tables above also show that there are $80,0 \%$ of the respondents who agree with the idea about the use of English learning accounts in Instagram as a media for learning English (vocabulary) and Instagram really supports vocabulary learning.It means Instagram can be a great educational tool.
Based on the finding above, the researcher classified the students' effect according to According kirstlinstagram can be a great educational tool that makes the educational process interesting and insightful.

The questionnaire shows that the students of 2019 third semester English tadris study programm IAIN Palu academic year 2020-2021 have high effect in learning vocabulary through Instagram because they feel are engaged in learning vocabulary.

Regarding to the average of the effect of using Instagram on the learning vocabulary the researcher has calculated it by using SPSS, where total score of questionnaire was divided with the total number of sample, so the result of the mean score calculated was $62,48 \%$ This result indicated that the effect of students are classified as high.

\section{Conclusion And suggestions}

Instagram has an effect in learning vocabulary of third semester students at English Tadris Study Programme in IAIN Palu academic year 2020/2021 revealed by mean score of the students' questionnaire. The mean score level was $62.48 \%$ as high category level. The researcher recommended students should be aware of their problem in learning vocabulary. They should know what makes their interested in learning vocabulary through Instagram so they can make an effort to increase their interested reason and maintain it.

The lecturers as one of the supporting of the students' success in learning vocabulary. They can use technology like notebook or smartphone which support internet connection to help them increase and maintain the students in learning vocabulary. 


\section{Datokarama English Education Journal Vol.2 No. 1, 2021}

\section{References}

Abbasova, M, "The Impact of Social Networks on the Students' English Language in Azerbaijan. International Multidisciplinary Scientific Conferences on Social Sciences and Arts,3', https://www.researchgate.net/publication $\$ 307967123$ The Impact of Social Net works on the Students' English Languag e in Azerbaijan (13 March 2021).

Amir, M. Taufik. 'MerancangKuesionerKonsep dan Panduan untuk Penelitian1Sikap,Kepribadian\&Peril aku,',2015.https://www.google.com /url?sa=t\&source=web\&rct=http://w ww.researchgate.net (15 Oktober 2020)

Arifin, 'Penelitian Pendidikan PendekatanKuantitatif\&Kualitatif', LilinPersada Press.https://www.google.com/url?s $\mathrm{a}=\mathrm{t} \&$ source=web\&rct=http://www.re searchgate.net (15 Oktober 2020).

Arikunto, S. ProsedurPenelitianSuatuPendekatan Praktek, RinekaCipta, Jakarta, 2002.https://www.google.com/url?s $\mathrm{a}=\mathrm{t} \&$ source $=$ web\&rct=http://www.re searchgate.net (15 Oktober 2020).

Bicen, H., \&Sadikoglu, S., \&Sadikoglu, G,' The Impact of Social Networks on Undergraduate Students Learning Foreign Language. Procedia: Social and Behavioral Sciences. https://www.researchgate.net/publication /344349821 (13 March 2021).

Cameron, L. 'Teaching languages to young learners," Cambridge University

Press.https://www.google.com/url?s $a=t \&$ source=web\&rct=http://reposit ory.ar-raniry.ac.id (01 Oktober 2020).

Collins, H. "Creative Research: The Theory and Practice of Research for the Creative Industries" AVA Publications, p.38, 2010. news.collinselt.com (10 November 2020).

Donald Ary, Lucy Chesser Jacobs, Chris Sorensen, and Asghar Razavieh, Introduction to Research in Education, Canada: Wadsworth, 2010. http://www.amazon.com (09 november 2020).

Ferlazoo, L. Creating Instgram Video ' Book Trailers" With English Language learners. 2014. Larryferlazzo.edublogs.org (09 December 2020)

Harackiewicz, Judith M \& Chris S. Hulleman,' The Importance of 1 Achievement Goals and Task Value in Promoting the Development of Interest.' A Journal compilation Blacwell, 2010. publishing ltd. Retrived from http:// psych.wisc.edu/cmsdocuments/Com passHH.pdf ( 04 October 2020).

Harmon, J. M., Wood, K. D., Hedrick, W.B., Vintinner,J., \&Willeford, T. "'Interactive1word walls: More than just reading the writing on the walls,' A Journal of Adolescent \& Adult Literacy. http://www.researchgate.net

$(04$ October 2020).

Hasnawati Hassan, 'Students Engagement In Online Learning: Learners Attitude Toward EMentoring,' 'www.researchgate.net (20 february 2021) 
Datokarama English Education Journal Vol.2 No. 1, 2021

Hatch, Evelyn and Brown. Vocabulary, Semantics, and LangaugeEducation.11Cambridge: CambridgeUniversityPress, 1995.www.uptjournals.net October 2020)

Henny mastuti. Thesis. 'PenggunaanInstgramuntukMening katkanPenguasaan https://www.google.com/url?sa=t\&s ource=web\&rct=http://repository.arraniry.ac.id (01 Oktober 2020)

Husaini Usman \& Purnomo Setyady Akbar," PengantarStatistika," https://www.yourarticlelibrary.com/hrm/i nterview-definition-objectives-types-andguidelines-for-effectiveinterviewing $/ 35268$

Kaplan, A.M. and Haenlein, M. (2010), "Users of the world, unite! The challenges and opportunities of social media", https://www.sciencedirect.com/scienc e/article/pii/S0007681309001232 (10 November 2020)

Kirst, Michael W. Instagram as an Educational Tool for College Students. 2018.

http://collegepuzzle.stanford.edu/?p $=5057$ Language .International Journal of Teaching and Education (01 October 2020)

Lewis, M. 'The Lexical Approach,'”Hove, England: Language Teaching Publications, 1993. https://www.google.com/url?sa=t\&s ource=web\&rct=http://repository.arraniry.ac.id (01 Oktober 2020)

Maryani.. "Media Sosialdalam Dunia Pendidkan", An-Nahdhah,2015. https://www.google.com/url?sa=t\&s ource=web\&rct=http://www.research gate.net (15 Oktober 2020)

Mattehws and Liz ross, 'Research Methods: A Practical Guide For The Social Sciences, 'Harlow, UK: Pearson Education, 2010. www.amazon.com (22 November 2020)

Meydina. Thesis. The effect of applying word sort strategy toward students' vocabulary mastery of the eight grade (Students At Smp Negeri 3 Palu ), 12019 .

Micahel W. Kirst. "A College Succes the College Puzzle," Stanford University,2016.: http://collegepuzzle.stanford.edu/?p $=5057$ Language. .International Journal of Teaching and Education ( 02Oktober 2020).

M. Taufik Amir,

'MerancangKuesionerKonsep dan

Panduan untukPenelitianSikap,

Kepribadian\&Perilaku,'”.

Opac.perpusnas.go.id (01 October 2020)

Mulyasari, E., \&Hartati, T. 'Meaningful Vocabularies Developed through Classroom Activities. Conferenced: 3rd International Conference on Early Childhood Education,". https://www.google.com/url?sa=t\&s ource=web\&rct=http://repository.arraniry.ac.id (01 October 2020)

Noraien, M. and Normaliza, A. R. "Instagram in ESL classroom," Man in India, 2017.https://www.researchgate.net/p ublication/321016352_INSTAGRA M_IN_ESL_CLASROOM $(01$ October 2020) 
Datokarama English Education Journal Vol.2 No. 1, 2021

Nurul zahriza .1ThelInfluence accoumt @ gurukumrd to the out of class Language1 Learning (Study on Easiness of Followers' English1Learning at State Islamic College of Sorong)',2019. https://www.google.com/url?sa=t\&s ource=web\&rct=http://www.research gate.net (15 Oktober 2020)

O'Leary,Z. 'The Essential Guide To Doing Your Research Project,"' London: Sage. Htttp://www.amazon.com (20 November 2020)

Pero Ali. Instagram in Learning English Language. from http://prezi.com/orhxy6Icpc8/instagram-in-learningssenglishlanguage/. (20 November 2020).

Qahtani, M. "The Importance of Vocabulary in Learning Language," 2015.

https://www.google.com/url?sa=t\&s ource=web\&rct=http://repository.arraniry.ac.id (01 Oktober 2020).

Ramdhany thesis. "Students Interest In Learning Vocabulary Through Instagram At The Fifth Semester Of English Department Of UinAlauddin Makassar," 2017. https://www.google.com/url?sa=t\&s ource=web\&rct=http://repository.ui n-alauddin.ac.id (04 Agustus 2020).

Riskawati Hajis. ''Improving Students' Vocabulary by Using Visual Media at Smp Negeri 10 Makassar."' 2014. http://www.News.unair.ac.id Oktober 2020).

Ronan Kelly. "An Exploration of Instagram to Develop ESL Learners' Writing Proficiency,' (Doctoral dissertation, Ulster University). London, United Kingdom: British Council, 2015. https://www.google.com/url?sa=t\&s ource=web\&rct=http://repository.arraniry.ac.id (01 Oktober 2020).

Schmitt, Nobert. "Vocabulary language teaching," Cambrigde:1Cambrigde, 2000.University Press. https://www.google.com/url?sa=t\&s ource=web\&rct=http://repository.arraniry.ac.id (01 Oktober 2020).

SuharsimiArikunto.

'Dasar-Dasar Pendidikan,",

https://www.google.com/url?sa=t\&s ource=web\&rct=http://repository.arraniry.ac.id (01 October 2020).

Sugiyono."MetodePenelitianKuantitatif, Kualitatif,"

https://www.google.com/url?sa=t\&s ource=web\&rct=http://repository.ui n-alauddin.ac.id (04 August 2020).

SutasiniSivagnanam, Melor Md Yunus,' Utilizing Social Media in Vocabulary Enhancement among Primary ESL Learners in 1Sekolah KebangsaanBatuKikir, Negeri Sembilan, Malaysia 2Faculty of Education, UniversitiKebangsaan Malaysia," : Universal Journal of Educational

Research.1 http://www.hrpbug.org (13 March 2021).

Thornbury, Scott. 'How to Teach Vocabulary," Person Education Limited.

https://www.google.com/url?sa=t\&s ource=web\&rct=http://repository.ui n-alauddin.ac.id (04 August 2020)

UlfaAzkiya. Students perception towards the impact of English learning accounts on instagram on students' vocabulary, 2019. https://www.google.com/url?sa=t\&s 
Datokarama English Education Journal Vol.2 No. 1, 2021

ource=web\&rct=http://repository.arraniry.ac.id (01 October 2020).

Ur, Penny. A Course in Language Teaching. Practice and Theory. Cambridge: Cambridge University Press, 1996.www.amazon.com (20 November 2020)

Venkatesh, V., Morris, M. G., Davis, G. B., \& Davis, F. D. User acceptance of information technology: toward a unified view. MIS Quarterly, 27 (3), 425-478. Doi: 10.2307/30036540 (01 October 2020)

Wahyu Hidayat dan Nur AsmawatiLawahid. Metode Fuzzy Delphi

UntukPenelitianSosial(Bandung), 2020.

Wiktor. K. A billion Dollar Idea: Instagram Language Learning. Studies in English Language Teaching, 2012. Retrieved on June 21, 218, from: https://bravelearning.com/2012/04/20 La-billion-dollar-idea-instagramandlanguage-learning (01 October 2020)
Wilkins, D. A. Linguistics in Language Teaching. Cambridge: MFT Press, 1972.

https://www.google.com/url?sa=t\&s ource=web\&rct=http://repository.arraniry.ac.id (01 October 2020).

Yadegarfar, H. \&Simin, S.1Effects of using

Instagram on learning grammaticall

accuracy of word classes among Iranian undergraduate TEFL students, 2016. International Journal of Research Studies in Educational Technology.

https://www.learntechlib.org/p/1733 62 (01 October 2020).

Zahirah Zainal, Noor HanimRahmat, "' Social Media and Its Influence on Vocabulary and Language Learning: A Case Study in UniversitiTeknologi Mara (Uitm), Shah Alam, Malaysia,": European Journal of Education Studies. :https://www.researchgate.net/publicatio n/344349821 (13 March 2021). 